\title{
Selangor Productive Waqf Expansion Form
}

\author{
Muhamad Hazrin Sayuti ${ }^{1}$, Baihaki Abdullah ${ }^{2}$, Ahmad Nazrul Alif Yahya ${ }^{3}$ \\ \{ayeinhaz@yahoo.com ${ }^{1}$, baihakiusm@gmail.com², nazrul_alif@ymail.com ${ }^{3}$ \} \\ Centre For Islamic Development Management Studies, USM, Malaysia ${ }^{123}$
}

\begin{abstract}
This paperwork discuss Selangor productive waqf expansion form that is implemented by Selangor Waqf Corporations (SWC) that is incorporated its management by the Selangor Islamic Council (SIC). Productive waqf as the main mechanism in giving support to the development of all ummah because of its dynamic attribute bringing positive changes in the development and welfare of the society. Thus, productive waqf is an important investment to ensure the benefits generated from waqf asset continues to remain productive and can be channelled continuously to mawkuf 'alaih. Productive waqf will give a big impact on the development of society in every aspect, both in terms of social or economic. Hence, the implementation of productive waqf needs to be creative, innovative, and proactive based on syari'e. The productive waqf aspect comprises of two main objectives which are to give a general understanding to readers about the productive waqf concept and implementation of productive waqf form under SWC. This research uses a qualitative methods that documents research while the collecting data is obtained through content analysis. The result shows that innovation implemented with the help of corporate companies has given wide opportunities to the waqf institution to expand its role and give greater benefits to society. It also gives a positive implication to understand the importance of productive waqf in Selangor hence increase the Muslim society's trust towards SIC to continue to waqf.
\end{abstract}

Keywords: Evolution, Development and Islamic based sustainable.

\section{Introduction}

Waqf is one of the "Islamic Social Institution" that is highly recommended in the Islamic teachings to be used by servant of Allah SWT that has wealth in terms of assets (movable or non-movable asset as a channel to channel their sustenance (Rizq) that is endowed by Allah SWT to the society to be used (1),(2)(3). Waqf is also one of the instruments to create justice and prosperity in the economy (4). He adds again, and this is due to the unique main characteristic of waqf thus the asset is not only his, but it has changed to Allah's belonging and enabling the asset to be fully and fairly utilized by the society

Next, the uniqueness of Waqf has made the function of waqf to be productive that is termed as productive waqf. This productive waqf manages to be an important role as an instrument of Islamic finance in generating the source of funding for the country and Muslim (5). Even though the practice of Waqf has been done since before the year 1950, however more systematic waqf management only started after the year 1958 (6). This then makes Selangor the first state that draft the law of waqf property, that is stated in the year of 1952 in the Selangor Islamic Council Management law. Other states follow the method of 
implementation of waqf by drafting the same law towards waqf assets including Melaka (1959), Terengganu (1965) and Johor (1978).

However, the awareness towards the function of productive waqf that can increase the socio-economy of the Muslim society in Malaysia only started around the 2000s after getting pressure by researchers about waqf. This leads to a positive change towards the waqf institution to have a more creative, innovative, and proactive role in the development of waqf asset such as zakat institutions (7),(8). With that, to make sure that the waqf institution in every state can be viable thus the Malaysian government established the Department of Waqf, Zakat, and Hajj (JAWHAR) in the year 2004 and Malaysia Waqf Foundation (YWM) on the year 2008 that is responsible in arranging, coordinate, and help MAIN in every state in Malaysia in identifying, managing, and developing waqf properties (9). To accommodate the fun requirements, the government will give appropriate allocations in RMK-9 and also RMK10 to manage the assets. Other than that, allocations are also inserted in the 2010 budget and with the allocations that are given by the government, waqf institution actively running development projects starting from the year 2008 and it has grown rapidly the to the year 2009 and 2010 (10).

In Malaysia, there are 14 National Islamic Religious Council that aims to make the Waqf management implemented systematically and effectively for the interests of the ummah. Every institution is given the power to manage the Waqf asset with the best practice standard and contemporary management system as a step to the Islamic Excellence Project (11). In addition, Selangor is one of the states that is directing to the positive approach with corporating waqf production under the Selangor Islamic Religious Council (SIC) that is Selangor Waqf Corporation (SWC). Next, this paper wishes to discuss the productive waqf forms under the supervision of SWC.

\section{Literature Reviews}

\subsection{Productive Waqf}

Waqf, in general, is not explained in any Quran verse concretely and textually. However, waqf concept includes in infaq fi sabilillah; thus the principle that is used by the jumhur ulama in explaining the waqf concept is based on the generalization of Quran verse that explains about infaq fi sabilillah which means to spend wealth for a certain purpose without asking any return but only for the sake of Allah SWT. This is based on the word of Allah SWT in alBaqarah that means:

"O ye who believe! Give of the good things which ye have (honourably) earned, and of the fruits of the earth which We have produced for you, and do not even aim at getting anything which is bad, in order that out of it ye may give away something, when ye yourselves would not receive it except with closed eyes. And know that Allah is Free of all wants and worthy of all praise.."

(Surah al-Baqarah, 2:267)

Among the essence that can be learned in this verse is that Islam requires its practitioners to help poor people like helping with money, property, and so forth which allows the receiver benefits from it. 
Waqf according to the understanding of Malaysian society is very traditional that only limits the waqf purpose as the ritual use of religion only (10),(12). While productive waqf originated from two words that are waqf and productive. However, waqf as definition by Ibnu Qudamah (t.t: 195) is tahbish al-Ashl wa tasbil al-Tsamrah (to detain the tree of asset and distribute its yield) has productive elements. This is due to the definition require that waqf needs to be productive because the items distributed and utilized only the yield of the tree of waqf asset while the tree is still maintained. This leads to the requirement of the muttawali to develop waqf asset so that it creates a product and then the yield can be distributed to the mawquf 'alaih while maintaining the basic of the Waqf asset without lacking either in value or the form of waqf asset (13).

By that, waqf is a savings and invest activity that moves parallelly (14). While productive is an adjective to the word production that is defined as a human activity to produce goods or services that is then utilized by consumers (15). Richard G. Lipsey that is taken from Rustam Effendi defined production as an action in making commodity, goods or either service (4).

Other than that, productive waqf also able to be one of the financial instrument that plays an important role in empowering the Muslims economy in particular. Waqf is not only grounded to a waqf asset such as books, equipment waqf and so forth but it has to be economical like waqf in the form of agriculture land or gardening, commercial building, that is worked until it produces profits that some of the yields are used to finance many other activities (16). Thus, it can bet the source of waqf from society to society (17). Next, describes productive waqf as waqf asset that is used for the production benefit and waqf asset operated to produce goods and then sold, and the yield is distributed suitable to the intention of the waqf giver (14).

In addition, according to, concluded that productive waqf has three main items (18). First, taking into account the durability of the Waqf asset that can be maintained and fulfil the waqf giver's attention. Secondly, waqf asset needs to be developed with many forms until it can create more assets while retaining the Waqf asset. Thirdly, waqf asset needs to fulfil the intentions of waqf giver in giving benefits (the function) to mawquf 'alaihi.

\subsection{Productive Waqf Property Form}

Based on the description made, productive waqf is the Waqf asset that is explicitly maintained by the trustee that is National Islamic Religious Council (SIRC) in every state. The purpose of the management of waqf property is to produce goods services until it was able to generate income financially until it is channelled to the deserved mawquf 'alaih. From this definition, muttawali is demanded to strive in maintaining and developing waqf asset. Maintaining and developing a waqf asset can be done in many ways. Among them is productive waqf asset in the form of agriculture fishery, gardening, trade, industry, workshop, hospitality, house and shop lots, and other forms such as investment using cash waqf, waqf stock scheme. The productive waqf asset form that is stated can be implemented to maintain and develop a waqf asset from year to year. Other than that, choosing the productive waqf asset form also needs to develop and variance accordingly parallel with the development of technology and era. A muttawali in choosing the form of effort that will be implemented of course needs to adjust the form of effort it will be implemented and to adjust with various factors such as the condition of waqf asset and current trend. Even though there are problems in lack of finance, however, it can overcome by implementing management with a third party. 


\section{Methodology}

This study has adopted a qualitative approach. A qualitative approach has been adopted since this study does not involve any statistical data. Additionally, a qualitative research is defined as an inquiry process of understanding a social or human problem based on either from the holistic picture, formed with words, reporting detailed views of informants and conducted in a natural setting (19). This approach is vital to this study to know how productive waqf is implemented towards expansion form as an alternative way to benefits society. In collecting data, a method has been used namely library research. This method was applied to obtain data from secondary sources. This includes journals, conference papers and websites. Finally, the data were analysed using the content analysis method.

\section{Result and Discussion}

\section{Productive Wakaf Form In Selangor}

The Selangor state has 710 waqf land lot that has the area of 352.67 hectares. In the previous year before the establishment of SWC, when SIC is collaborating with JAWHAR, YWM and the state government, they have implemented the development project of waqf property that is categorized as religious, education, business, and a service project. Table 1. shows a few forms of productive waqf property in Selangor.

Table 1. Selangor Productive Waqf Property Development Form

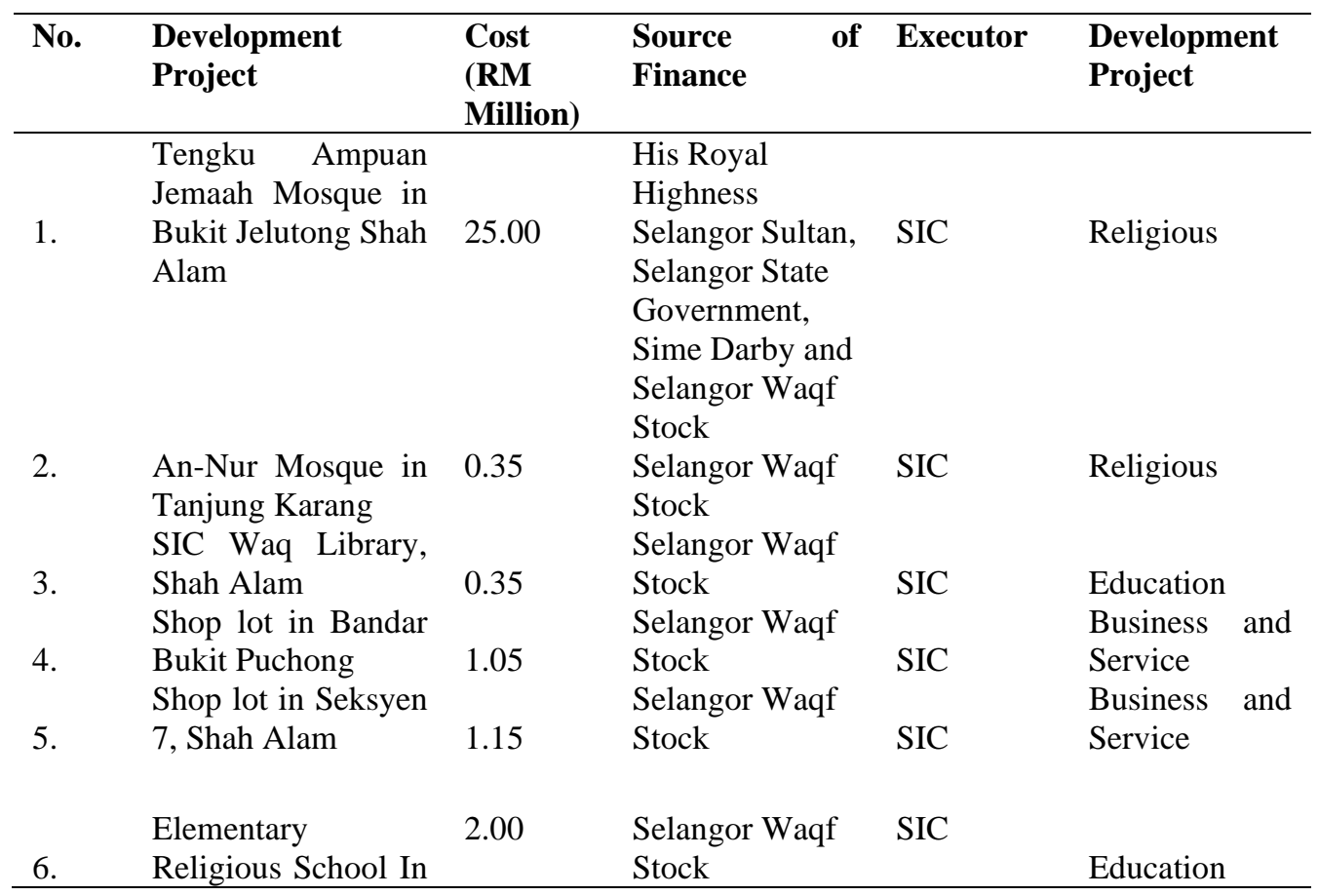




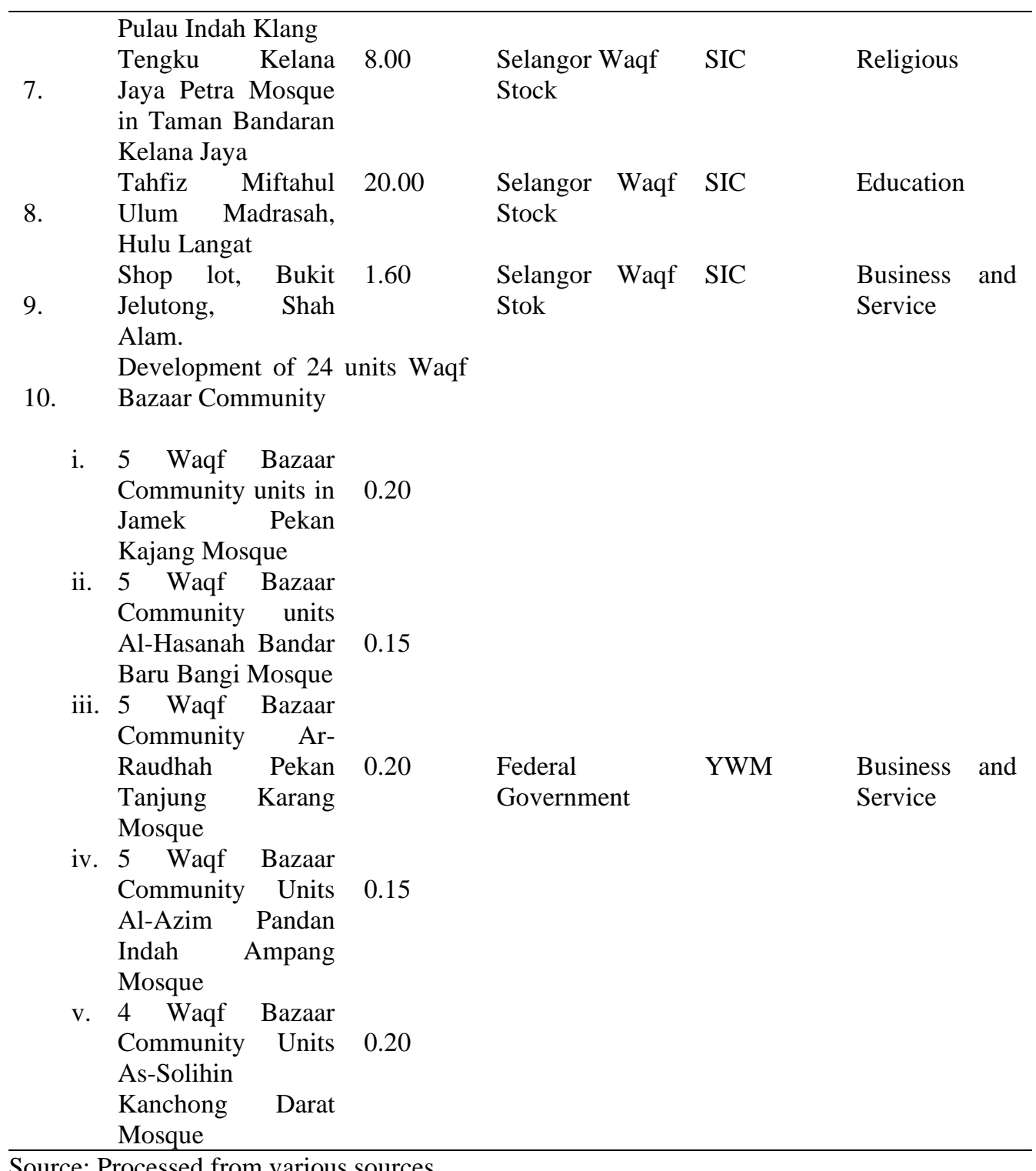

Source: Processed from various sources

Based on Table 1.1, the commercial building construction is limited to shop lots and the development of 24 units Waqd Bazaar. The development based on socio-education and religion dominates the development of waqf property in Selangor. However, the commercial development in Selangor is gaining place after SWC established.

Realizing the importance of productive waqf, SWC has appointed Nada Sepakat Corporation (M) Sdn. Bhd on 20th March 2014 that is responsible for implementing the development of waqf property. The Nada Sepakat Corporation (M) Sdn. Bhd company is appointed as the developer for the project of development joint venture that the concept is based on Semi-D 1 1/2 Floor House for eighty (80) units on the waqf land GM 248 and Lot 
3734 GM 249 Batu 8, Jalan Kebun, Daerah Klang that has been waqf by Almarhum Abdul Rahman Ali for the benefits of Al-Falah Telok Pulai Musolla measuring 2.3 hectare in Jalan Kebun. The buying concept of this house is based on the Al-Ijarah (Islamic lease) concept where "buyers will own the house on the waqf land for 99 years".

However, in successfully implementing all forms of development planned, SWC needs to empower its function to multiply its waqf fund. Lack of funding in developing waqf asset is synonym as the main challenge in any waqf institutions in Malaysia.

\section{SWC Efforts In Increasing Selangor Waqf Fund}

By that, many efforts have been carried out by the SWC during the period of six years of its establishments to make sure the waqf fund keeps on increasing. Among the efforts that are done is to give understanding to the society towards the importance of waqf. Multiple media is used to educate the public such as advertisements on the radio, newspaper, magazine, bulletin, lectures, expo, carnival and websites.

On 21st until 23rd of June 2013, SWC has collaborated with the Malaysian Islamic Understanding Institute (IKIM) to organize the IKIM Mahabbah Carnival This carnival is responsible for promoting waqf to the public in conjunction with Selangor Waqf Month, while to focus on the industry, corporate, and company groups in joint venture to give an understanding about waqf, SWC launch Industry Friendly Month Campaign (BUMI) all October, November, and December every year and invites them to participate in Corporate Waqf Friend (20). The activities are forums and group sermons that involves 45 mosques in the industrial area other than workshop, course, and seminar programs (20).

The involvement of corporate entity in the waqf business affairs also is known as corporate waqf that is a stepping stone in increasing the interest and attention of the society in involving themselves in welfare activities like waqf. Among the company that is visited by SWC on 2011 to promote waqf is Puncak Niaga Holdings Berhad, Tenaga Nasional Berhad, Telekom Malaysia Berhad, Perodua Sdn Bhd, Johawaki Sdn Bhd, Permodalan Negeri Selangor Berhad, and Mydin Holdings Berhad.

Not only that, but SWC also collaborate with Karangkraf using the Sinar Harian medium and 29 magazines issued by Karangkraf to deliver the waqf campaign to the society. Karangkraf has been appointed as the SWC media partner. The welfare campaign to the readers and inner circle campaign to the staffs can encourage Karangkraf staffs to infaq using the convenience of payroll deductions to support Selangor Waqf Stocks (21).

Other than giving an understanding to the society about waqf, SWC wishes to do a few transformations in the management and development aspect of waqfs in Selangor to increase the waqf fund. The contemporary concept which is the popular cash waqf and has been implemented in a few countries has encouraged SWC to launch cash waqf scheme that enables individuals and organizations to waqf with a very minimum rate. This matter continues to record SWC's performance from the year 2011 until 30th September 2017 as much as RM207 million (22). Other than that, there is also an increase in the waqf land to 1,328 lots that have the area of 1,351 acres. 


\section{Conclusion}

It is undeniable SWC as a trustee to the people of Selangor and SIC, in particular, has conducted well on its obligations regarding waqf fund yield. Innovation implemented with the help of corporate companies has given wide opportunities to the waqf institution to expand its role and give greater benefits to society. However, SWC needs to diversify more waqf property form like the development of hospitality, industry, agriculture and so forth. This is because the development of waqf property is significant to the improvement of socioeconomy. The positive change towards the waqf fund collection is not enough. Hopefully with the implementation of such productive waqf can continue to contribute benefits to mawquf 'alaih even the profits can add more new waqf properties.

\section{References}

1. Sains Malaysia U, Shaifull Anuar A, Bahari Z, Doktoralina CM, Indriawati F, Nugroho L. The Diversity Of Waqf Implementations for Economic Development in Higher Education Centre For Islamic Development Management Studies (ISDEV) Universiti Sains Malaysia. Ikon J Ekon dan Bisnis Islam [Internet]. 2019;4(1). Available from:

https://ejournal.radenintan.ac.id/index.php/ikonomika

2. Nasution, M. E., \& Hasanah U. Wakaf Tunai Inovasi Finansial Islam: Peluang dan Tantangan dalam Mewujudkan Kesejahteraan Umat. Pusat Kajian Timur Tengah dan Islam Universitas Indonesia. 2006;

3. Othman MZ. Islamic Law: With Special Reference to the Institution of Waqf. Prime Minister's Department, Religious Affairs Division. 1982;

4. Effendi, R., Mth, A., \& Syibly MR. Produksi Dalam Islam. Magistra Insania Press. Esposito, J. L. (2001). Ensiklopedi Oxford Dunia Islam Modern. Mizan; 2003.

5. Ambrose AHAA, Aslam M, Hanafi H. The Possible Role of Waqf in Ensuring a Sustainable Malaysian Federal Government Debt. Procedia Econ Financ [Internet]. 2015;31(15):333-45. Available from: http://dx.doi.org/10.1016/S2212-5671(15)01205-8

6. Mahamood SM. Perundangan wakaf dan isu-isu berbangkit. Konvensyen Wakaf Kebangsaan 2006. 2006.

7. Doktoralina CM, Bahari Z. Zakat Accounting Information System in Private Higher Education. 2018;XXI(Special 3):265-75.

8. Doktoralina, C. M., Ilias, N. A., Bahari, Z., Waluyo, W., \& Suryadhi J. Investment of Zakat Fund in Malaysia Caturida. J Soc Sci Res [Internet]. 2019;5(4):999-1004. Available from: https://doi.org/https://doi.org/10.32861/jssr.54.999.1004

9. Zahri Hamat. Substitution Of Special Waqf (Istibdal): Case Study At The Religious And Malay Custom Council Of Kelantan (MAIK). Macrotheme Rev. 2014;3(4):64-71.

10. Ahmad S. Institusi Wakaf dan Pembangunan Ekonomi Negara : Kes Pembangunan Tanah Wakaf di Malaysia Wakaf Institutions and National Economic Development : A Case on Wakaf Land Development in Malaysia. Pros PERKEM VI. 2011;1:138-47.

11. Hasan, Z., \& Abdullah MN. The investment of waqaf land as an instrument of muslims' economic development in Malaysia. In Dubai International Conference on Endowments' Investment. 2008;4-6.

12. Mutalib HA\& R, Hasyeilla Abd Mutalib RAR. Kajian Perbandingan Antara Majlis Agama Islam Negeri ( MAIN ) dan Pentadbir. 2015;(January).

13. Mubarok J. Wakaf Produktif. Jawa Barat,Indonesia: Simbiosa Rekatama Media; 2008.

14. Kahf M. al-Waqf al-Islami. Tatawurruhu, Idaratuhu, Tanmiyatuhu. 2000.

15. Ali M. Prisip dasar produksi dalam ekonomi islam. Lisan Al-Hal: Jurnal Pengembangan 
Pemikiran Dan Kebudayaan. J Pengemb Pemikir Dan Kebud. 2013;5(1):19-35.

16. Bakar D. Wakaf Instrumen Kewangan atau Keagamaan? 2017; Available from: www.usim.edu.my/ms/berita/

17. Kurniawan M. Wakaf Produktif Dan Pemberdayaan Ekonomi Umat. J Asas [Internet]. 2013;(Vol 5, No 1 (2013): ASAS JURNAL HUKUM DAN EKONOMI ISLAM):43. Available from: http://ejournal.iainradenintan.ac.id/index.php/asas/article/view/157

18. Bahari, Z., \& Hassan SHM. Pembangunan Wakaf Produktif: Kes Kajian di Pulau Pinang. In Koferensi Internasional Pembangunan Islam 3, Universitas Jember, Jawa Timur, Republik Indonesia (p. 17). Jember Indonesia. 2016;

19. Creswell JW. Research Design, Pendekatan Metode Kualitatif, Kuantitatif, dan Campuran (Terjemahan). Yogyakarta: Pustaka Pelajar. 2016. 85-100 p.

20. Malaysia U. Karnival Mahabbah IKIMfm. 2013; Available from: www.wakafselangor.gov.my/index.php/galeri/keratan-akhbar/241-21-\%0906-2013-utusanmalaysia-karnival-mahabbah-ikim-fm

21. Harian S. Karangkraf jadi rakan media PWS. Utusan Malaysia. (2012). Tingkat Kesedaran Wakaf [Internet]. 2019; Available from: www.wakafselangor.gov.my/index.php/galeri/keratanakhbar/243-13-\%0A11-2012-utusan-malaysia-tingkat-kesedaran-wakaf\%0A\%0A

22. Selangor W. Prestasi PWS 2011. 2017; Available from: www.wakafselangor.gov.my/index.php 